\title{
Perancangan Aplikasi Berbasis Android untuk Pemeriksaan Pengelasan pada Bangunan Kapal Baru
}

\author{
Reiza Achmafajri dan Triwilaswandio Wuruk Pribadi \\ Departemen Teknik Perkapalan, Fakultas Teknologi Kelautan, Institut Teknologi Sepuluh Nopember (ITS) \\ Jl. Arief Rahman Hakim, Surabaya 60111 Indonesia \\ e-mail: triwilas@na.its.ac.id
}

\begin{abstract}
Abstrak-Kegiatan pemeriksaan pengelasan pada pembangunan kapal baru yang ada saat ini masih dilakukan secara manual dimana seorang welding inspector melakukan pemeriksaan mengacu pada form pemeriksaan. Kegiatan pemeriksaan pengelasan yang ada saat ini kurang efektif untuk dilakukan pada proses pembangunan kapal baru, hal ini dikarenakan minimnya fungsi pengawasan dan kontrol dari welding inspector yang menyebabkan terjadinya pemeriksaan ulang dan pekerjaan ulang. Tujuan dari studi ini adalah melakukan observasi sistem pemeriksaan pengelasan pada pembangunan kapal baru yang ada saat ini, merancang aplikasi berbasis android untuk panduan pemeriksaan pada pembangunan kapal baru, dan melakukan uji validitas aplikasi tersebut dalam meningkatkan efektivitas pemeriksaan pengelasan pada pembangunan kapal baru. Perancangan aplikasi dilakukan dengan pembuatan mock up aplikasi, desain interface, perancangan database, dan pengkodingan aplikasi tersebut. Aplikasi ini memiliki fitur daftar proses pemeriksaan, review hasil pemeriksaan, progress pemeriksaan pengelasan pada kapal, dan menu untuk menambahkan welding inspector. Uji coba aplikasi ini dilakukan kepada beberapa responden yang memiliki pengalaman pengawasan pembangunan kapal baru dan pihak-pihak yang memiliki latar belakang pendidikan di bidang perkapalan. Dari hasil pengujian menggunakan kuisoner tersebut diperoleh kesimpulan bahwa aplikasi ini perlu diaplikasikan dalam mendukung proses pemeriksaan pengelasan pada pembangunan kapal baru.
\end{abstract}

Kata Kunci- Aplikasi Android, Pemeriksaan Pengelasan Kapal, Welding Inspector, Aplikasi Android Pemeriksaan Pengelasan pada Bangunan Kapal Baru.

\section{PENDAHULUAN}

$\mathrm{D}$ ALAM bidang perkapalan, proses pembangunan kapal baru perlu adanya pengawasan khusus pada setiap proses produksi pembangunan kapal. Hal itu dikarenakan kapal memiliki komponen - komponen penyusun yang cukup kompleks dan membutuhkan pengawasan dan pengecekan untuk menjamin mutu kualitas hasil pengerjaan kapal yang baik. Salah satu proses pengecekan pada saat pembangunan kapal baru yaitu proses pengecekan cacat las pada pelat kapal. Oleh karena itu, untuk menjamin kualitas mutu hasil pengelasan pada bangunan kapal baru agar tetap sesuai standar dibutuhkan proses pemeriksaan pengelasan pada kapal. Survei ini dilakukan guna mengetahui kondisi aktual kapal setelah dilakukan pengelasan, cacat las yang timbul, penanganan lebih lanjut terkait cacat las yang timbul, serta rekomendasi-rekomendasi terkait. Setelah data tersebut diperoleh, pihak galangan ataupun yang terkait akan melakukan studi kelayakan dalam pengambilan keputusan untuk dilakukannya reparasi atau perbaikan[1].

Proses pemeriksaan ini dilakukan oleh Welding Inspector atau pihak terkait. Dalam melakukan proses pemeriksaan dibutuhkan Welding Inspector yang berpengalaman dan memiliki pengetahuan yang memadai. Hasil pemeriksaan pengelasan ini akan dikemas dalam bentuk laporan yang tentu saja akan memakan waktu yang relatif lebih lama.

\section{STUDI PUSTAKA}

\section{A. Pemeriksaan Pengelasan Kapal}

Inspeksi las adalah kegiatan inspeksi pada sambungan las baik pada peralatan yang masih dalam tahap instalasi (pemasangan), konstruksi (pembuatan) maupun fabrikasi (perakitan) untuk memenuhi persyaratan spesifikasi, desain dan standar yang telah ditetapkan. Tujuan pemeriksaan pengelasan pada kapal adalah menjamin terlaksananya pelaksanaan sistem kontrol kualitas mutu di kapal yang memenuhi persyaratan sesuai dengan [2]:

1. ASME Section IX. 2010 dan AWS D1.1

2. Peraturan Class baik itu BKI, $L R, G L$ dan Lain-lain

3. Japan Shipbuilding Quality Standard ( J.S.Q.S )

4. Welding Procedure Specification (WPS ).

\section{B. Manfaat Pemeriksaan Pengelasan pada Kapal}

Pemeriksaan pengelasan mempunyai beberapa manfaat, antara lain [3]:

1. Mengetahui kondisi hasil pengelasan pada kapal tiap proses.

Pemeriksaan ini dilakukan untuk mengetahui kondisi terkini dari suatu kapal setelah dilakukan proses pengelasan.

2. Mengetahui potensi kerusakan lebih lanjut.

Setelah mengetahui kondisi dari hasil pemeriksaan pengelasan suatu kapal, maka dapat diketahui potensi kerusakan akibat cacat las tersebut beserta cara penanggulangannya.

3. Kejelasan dokumen. 
Pemeriksaan pengelasan juga sebagai alasan untuk melakukan pembaruan terhadap dokumen-dokumen yang berkaitan proses pembangunan kapal.

\section{Komponen Dalam Pemeriksaan Pengelasan Kapal}

Didalam sebuah standar pemeriksaan pengelasan ASME Section IX telah dijelaskan beberapa aspek atau komponen didalam pekerjaan pemeriksaan pengelasan pada kapal yang harus dilakukan pada saat kualifikasi prosedur. Komponenkomponen tersebut adalah sebagai berikut:

1. Prosedur las dan peralatannya

2. Persiapan sisi

3. Posisi pengelasan

4. Pemanasan awal dan suhu antar lajur

5. Kecepatan pengelasan

\section{Welding Inspector}

Seorang Welding Inspector menyiapkan laporan untuk Manager Quality Control di galangan yang akan menilai dua hal:

1. Hasil pemeriksaan pengelasan kapal secara umum.

2. Cara-cara untuk memperkecil risiko yang ada.

Tugas welding inspector (Inspektur Las) yaitu bertanggungjawab terhadap masalah dari kualitas pengelasan. Semua variable pengelasan harus sesuai dengan Welding Procedure Specification (WPS), Procedure Qualification Record (PQR), dan code yang sudah ditetapkan sebelumnya. Bila pada suatu sambungan ada yang terjadi indikasi cacat maka tugas Welding Inspector tersebut adalah untuk menentukan dengan cepat bahwa indikasi tersebut termasuk defect atau tidak. Jika termasuk defect juga masih perlu dilakukan pengecekan apakah masih dalam batas toleransi code. Jika sudah melewati batas toleransi code maka harus dilakukan repair. Sedangkan secara umum tugas welding inspector yaitu harus mengawasi, memeriksa dan memverifikasi kegiatan mulai dari sebelum, saat pengerjaan, maupun setelah proses pengelasan. Welding inspector tidak sendirian dalam melakukan proses - proses tersebut diatas. Biasanya bagian quality control galangan akan membantu dalam hal proses pengawasan secara rutin harian terhadap pengerjaan pengelasan pada proyek bangunan kapal baru yang sedang berlangsung. Nantinya laporan harian quality control akan dipelajari dan diberi tanggapan tindakan / keputusan dari welding inspector berikut saran untuk kelanjutan pengerjaan proyek berdasarkan standar dan aturan yang telah disepakati. Hal yang harus dilakukan pengecekan termasuk juga kelengkapan dokumen-dokumen.

\section{E. Aplikasi Berbasis Android}

Android adalah Operating System untuk alat komunikasi seperti ponsel pintar dan komputer tablet. Dikembangkan oleh Open Handset Alliance dipimpin oleh Google. Android menggunakan mesin virtual Dalvik hanya dalam penyusunan waktu untuk menjalankan dikompilasi kode Java. Android memiliki komunitas pengembang yang besar membuat aplikasi "apps" yang memperluas fungsionalitas dari perangkat [4]. Pada awalnya sistem operasi ini dikembangkan oleh Android Inc. yang kemudian dibeli oleh Google pada tahun 2005.

\section{METODOLOGI PENELITIAN}

\section{A. Studi Literatur dan Studi Lapangan}

Studi literatur adalah studi teori-teori yang akan digunakan dalam menyelesaikan studi serta untuk lebih memahami permasalahan yang akan dibahas dalam studi ini. Referensireferensi untuk mengerjakan studi ini didapat dari buku, jurnal ilmiah, paper, studi sebelumnya yang masih berkaitan, serta browsing dari internet yang kompeten dan dapat dipertanggungjawabkan. Selanjutnya yaitu melakukan studi lapangan apakah teori yang didapatkan memiliki relevansi sehingga kedua metode studi ini dapat mengarah pada sinkronisasi berupa problem solving. Dasar teori yang menjadi fokusan untuk ditelaah antara lain :

- Dasar teori pemahaman secara umum tentang kapal dan proses pembangunan kapal baru.

- Dasar teori pemahaman pemeriksaan pengelasan pada kapal.

- Mekanisme merancang program aplikasi berbasis android menggunakan bahasa pemrograman yang sederhana untuk dipelajari.

- Implementasi panduan pemeriksaan pengelasan ke dalam program aplikasi.

\section{B. Pengumpulan Data}

Pengumpulan data disini merupakan data-data yang dijadikan dasar untuk melakukan proses perancangan aplikasi berbasis komputer. Data-data yang dibutuhkan untuk pengerjaan studi ini yaitu;

- Data mengenai metode pemeriksaan pengelasan pada bangunan kapal baru yang dilakukan oleh Welding Inspector. Data berupa prosedur pemeriksaan, item-item pemeriksaan, dan metode penyajian laporan hasil pemeriksaan. Dalam penelitian ini beberapa keterangan data didapatkan berdasarkan wawancara pada seorang expert.

- Data kategori cacat las yang umum terjadi di kapal dan spesifikasi tekniknya sesuai dengan batasan yang telah ditentukan

- Data mekanisme perancangan aplikasi berbasis android.

Data perihal aplikasi berbasis android yang dapat memberikan representasi bahwa proses pemeriksaan pengelasan pada bangunan kapal dapat dilakukan lebih mudah melalui aplikasi yang akan dibuat. Data-data tersebut diperoleh dari beberapa literatur atau referensi yang ada di internet, text book, artikel, jurnal, diktat serta judgement ekspertis dan lain sebagainya.

\section{Pengolahan Data}

Tahap pengolahan data dilakukan setelah data-data dari berbagai sumber referensi telah terkumpul. Berdasarkan batasan yang telah ditentukan, berikut mekanisme analisis dan pengolahan data dalam penelitian ini: 
- Pengelompokkan bagian kapal untuk dijadikan bahan dalam merancang sistem manajemen data pada aplikasi yang akan dirancang.

- Pembuatan kalimat panduan pemeriksaan pengelasan yang mudah dipahami. Panduan pemeriksaan ini akan disajikan pada aplikasi yang akan dibuat dan dapat di akses Welding Inspector sebagai user ketika melakukan pemeriksaan pengelasan.

- Pembuatan template pemeriksaan pengelasan berdasarkan hasil pengelompokkan tahapan proses pembangunan kapal.

- Pembuatan moke up aplikasi android.

\section{Perancangan Program Aplikasi Android}

Aplikasi android dirancang dengan menggunakan program sublime text 2 yang merupakan program text editor untuk menulis bahasa pemograman. Dalam perancangan database, penulis menggunakan aplikasi database PostgreSQL dengan hosting di server dengan alamat yang dapat diakses yang didalamnya terdapat fasilitas PHPPGadmin.

\section{PEMERIKSAAN PENGELASAN KAPAL}

\section{A. Sistem Pemeriksaan Pengelasan Kapal Saat Ini}

Inspeksi las adalah kegiatan inspeksi pada sambungan las baik pada peralatan yang masih dalam tahap instalasi (pemasangan), konstruksi (pembuatan) maupun fabrikasi (perakitan), atau peralatan yang telah purna instalasi / konstruksi /fabrikasi namun belum pernah dioperasikan, maupun pada sambungan las dari peralatan yang sedang atau telah pernah dioperasikan atau peralatan lama yang diperbaiki atau dirubah, untuk memenuhi persyaratan spesifikasi, desain dan standar yang telah ditetapkan. Untuk pembagian aktifitas pekerjaan pemeriksaan pengelasan, sebelumnya tiga pihak (three parties) yang terdiri dari class, galangan dan welding inspector telah menentukan perjanjian atau persetujuan apa saja yang harus dilakukan inspeksi (inspection agreement) yang terdapat pada persetujuan tiga pihak (tripartite agreement). Dalam melakukan pemeriksaan pengelasan pada kapal, dapat dilakukan ketika bagian kapal atau sambungan telah dilakukan. Biasanya seorang welding inspector bertanggung jawab tidak hanya kepada satu kapal melainkan beberapa kapal. Dalam melakukan pemeriksaan, seorang welding inspector akan membawa daftar pemeriksaan yang dikeluarkan oleh kantor pusat. Daftar ini berisi komponen-komponen kapal yang akan di inspeksi dan disajikan dalam bentuk checklist / form pemeriksaan. Seorang welding inspector akan melakukan pengisian daftar hasil pemeriksaan berdasarkan apa yang ditemukan di lapangan dan melakukan dokumentasi berupa foto. Pengisian dilakukan secara tulis tangan manual oleh welding inspector dengan melengkapi checklist yang ada dan dapat dilakukan pengisian catatan tambahan apabila diperlukan.

Pemeriksaan yang dilakukan seorang welding inspector terintegrasi dengan welder dan quality control yang ada di lapangan. welding inspector akan menerima laporan dari quality control mengenai kerusakan-kerusakan yang ada, dan meninjau secara langsung. Hal ini bertujuan agar proses pemeriksaan dapat berjalan lebih singkat, sehingga laporan hasil pemeriksaan dapat segera dikemas dan disampaikan kepada pihak galangan atau pihak terkait dan segera dilakukan pengambilan keputusan untuk dilakukannya repair I maintenance ataupun rework oleh galangan atau pihak terkait.

Dalam melakukan penyajian laporan hasil pemeriksaan, daftar pemeriksaan yang telah dilengkapi oleh weldingi inspector akan di rekap pada komputer. Laporan pemeriksaan yang disajikan akan dilengkapi keterangan dan foto sebagai bukti pendukung kondisi aktual di lapangan. Laporan hasil pemeriksaan yang sudah disampaikan kepada pihak galangan atau pihak lain terkait, akan direkap sebagai acuan bahan pertimbangan untuk dilakukannya perbaikan sebagai bentuk perencanaan inspeksi.

\section{B. Welding Inspection Table List}

Welding inspection table list dikeluarkan perusahaan galangan kapal yang sedang dibangun sebagai acuan untuk seorang Welding Inspector melakukan pemeriksaan pengelasan di lapangan. Form ini menampilkan daftar bagian-bagian dari kapal yang hendak dilakukan pemeriksaan seperti yang ditampilkan pada Tabel 1 yang merupakan salah satu contoh welding inspection table list dari PT. Daya Radar Utama.

Tabel 1.

Contoh welding inspection table list kondisi kapal PT. Daya Radar Utama Welding Schedule

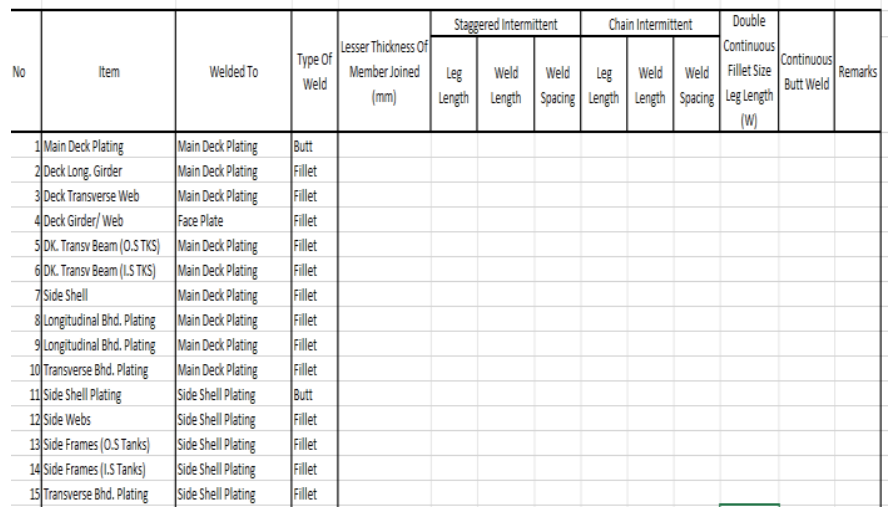

\section{Bentuk Laporan Hasil Pemeriksaan}

Bentuk laporan yang disajikan dalam sistem tersebut adalah print out dari laporan yang diketik secara langsung berdasarkan data yang diperoleh dari welding inspection table list ketika Welding Inspector melakukan pemeriksaan pengelasan. Bentuk laporan survei dapat dilihat pada Gambar 1 berikut. 


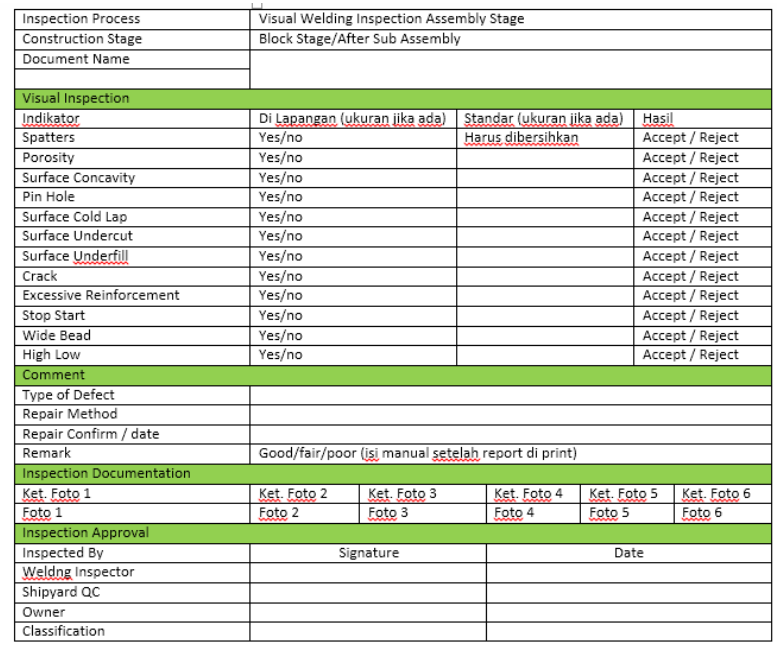

Gambar 1. Contoh laporan hasil survei pengelasan kapal PT. Anggrek Hitam

Penyajian laporan survei kondisi seperti Gambar 1 pada halaman sebelumnya dilakukan secara manual tanpa adanya sistem komputerisasi. Adapun bentuk laporan pemeriksaan pengelasan terdiri dari:

1. Laporan Pengawasan

Laporan yang berisi segala sesuatu pada bagian kapal yang diperiksa. Laporan ini merupakan laporan hasil rekapan dari list pemeriksaan yang telah dilengkapi Welding Inspector ketika melakukan pemeriksaan pengelasan pada kapal.

2. Dokumentasi

Dalam upaya melengkapi data dan informasi pemeriksaan pengelasan, seorang Welding Inspector menggunakan foto hasil dokumentasi yang didapatkan ketika melakukan pemeriksaan pengelasan pada kapal.

\section{Kelemahan Pemeriksaan Pengelasan Saat Ini}

Proses pemeriksaan pengelasan yang dilakukan saat ini dilakukan secara manual dengan lembaran welding inspection table list yang diisi oleh Welding Inspector ketika melakukan pemeriksaan pengelasan pada kapal. Welding inspection table list yang ada akan diolah secara manual dengan pengetikan manual ke laptop atau $p c$ dan disajikan dalam bentuk laporan yang disertai gambar dokumentasi. Hal ini tentu saja kurang efektif dikarenakan membutuhkan waktu yang cukup lama. Sehingga diperlukan adanya suatu metode baru yang dapat membantu proses pemeriksaan pengelasan pada kapal oleh Welding Inspector.

\section{PERANCANGAN PROGRAM APLIKASI}

\section{A. Penjelasan Umum Program Aplikasi}

Aplikasi ini menyajikan dua fungsi $\log$ in, dimana $\log$ in yang pertama ditujukan kepada Administrator. Fungsi $\log$ in Administrator ditujukan kepada manager quality control yang memiliki wewenang untuk melakukan editing parameter pemeriksaan dan mengakses laporan hasil pemeriksaan. Fungsi $\log$ in yang kedua ditujukan kepada User. User merupakan seorang Welding Inspector yang hendak melakukan survei kondisi. User dapat memanfaatkan aplikasi ini untuk melakukan pemeriksaan pengelasan pada kapal. Pengisian form pemeriksaan yang disajikan pada aplikasi ini akan dilengkapi oleh User sesuai dengan fakta yang ada dilapangan. Hasil pemeriksaan akan simpan ke server sehingga laporan dapat segera diakses oleh Administrator selaku pihak penjamin kualitas mutu hasil pengelasan kapal di galangan.

\section{B. Penyusunan Database}

Dalam perancangan database, penulis menggunakan aplikasi database PostgreSQL dengan hosting di server dengan alamat yang dapat diakses yang didalamnya terdapat fasilitas PHPPGadmin. Untuk mengakses database, ada beberapa langkah yang harus dilakukan, sebagai berikut :

1. Akses alamat melalui web browser (Mozilla Firefox atau

Google Chrome). Kemudian log in seperti yang ditampilkan pada Gambar 2 berikut.

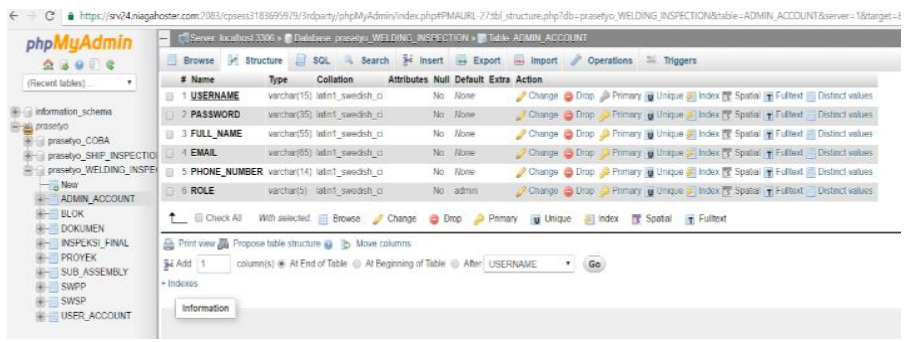

Gambar 2. Tampilan log in Phppgadmin

2. Untuk membuat database yang baru, maka harus create new database. Setiap database akan tersusun dari tabeltabel. Setiap tabel didalam database menggambarkan entitasnya. Setiap tabel tersusun dari berbagai attribute dari entitas. Setiap tabel juga terdapat satu attribute sebagai primary key dan foreign key. Primary key adalah suatu elemen record yang dipakai untuk menemukan record tersebut pada waktu diakses atau digunakan untuk identifikasi tiap record, Sedangkan Foreign key adalah suatu elemen record yang menunjukkan hubungan antara entitas satu dengan yang lainnya [5]. Proses pembuatan database baru dapat dilihat pada Gambar 3 berikut.

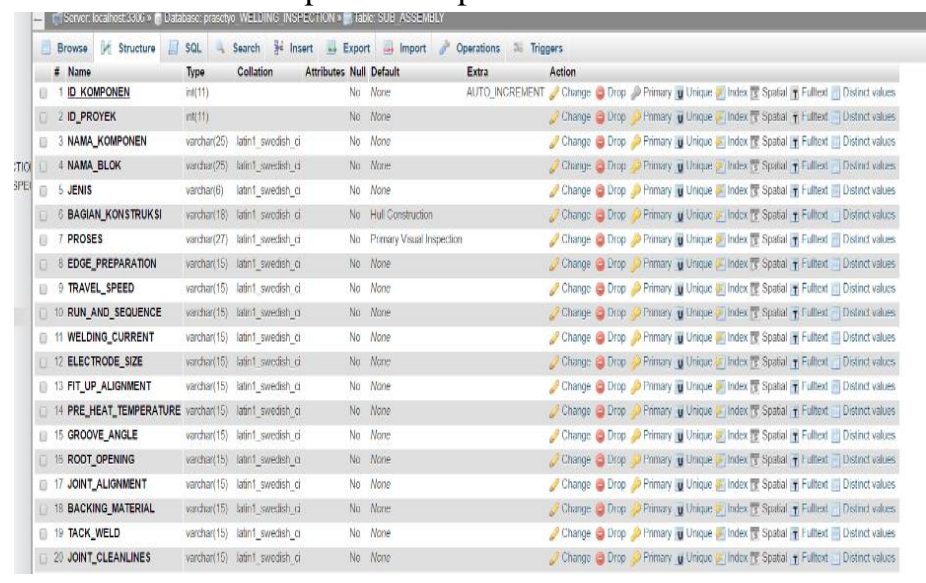


Gambar 3.Daftar Tabel/entitas dalam database postgreSQL

\section{Simulasi Aplikasi}

Adapun simulasi tampilan aplikasi berbasis android untuk pemeriksaan pengelasan pada kapal adalah sebagai berikut;

\section{- Administrator}

Administrator adalah super User disini. Administrator memiliki otoritas penuh pada program ini, dimana Administrator dapat mengisi data informasi untuk persiapan pemeriksaan dan juga fungsi edit. Administrator juga mampu melihat serta mengubah laporan hasil pemeriksaan. Daftar otoritas Administrator;

- Mengisi dan merubah identitas kapal.

- Mengisi dan dapat menggunakan fungsi edit dalam pengisian database.

- Dapat melihat dan merubah laporan hasil database.

- Melihat detail profil Welding Inspector

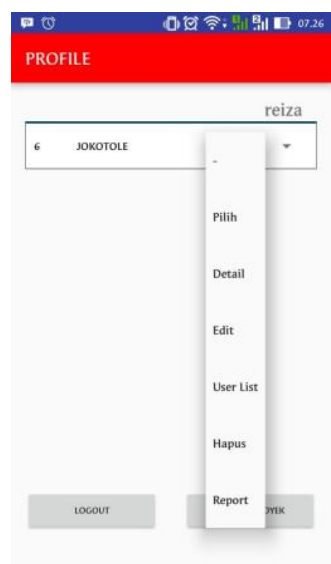

(a)

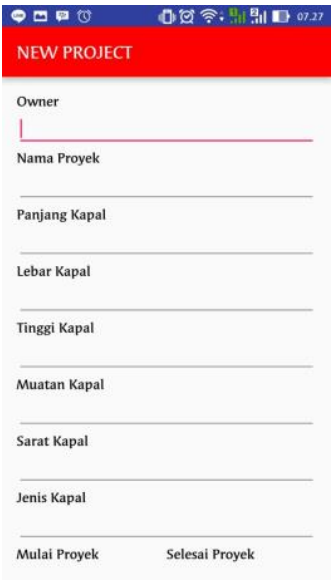

(b)
Gambar 4.(a) Fasilitas menu pilihan pada aplikasi dan (b) Proses pengisian data kapal

Gambar 4(a) merupakan tampilan dari menu utama setelah Administrator melakukan $\log$ in. Pada halaman menu akan ditampilkan beberapa pilihan untuk Administrator dalam menjalankan aplikasi android. Pada kondisi ini penulis akan memilih тепи masukkan data pemeriksaan sehingga akan ditampilkan form pengisian data kapal seperti Gambar 4(b) diatas. Data kapal yang diisi oleh Administrator akan tersimpan pada server dan dapat di akses untuk ditampilkan pada aplikasi yang akan digunaka User. Hal ini bertujuan untuk mempermudah User dalam memilih dan menampilkan data kapal yang hendak di survei tanpa harus dilakukannya pendataan dari awal oleh User.

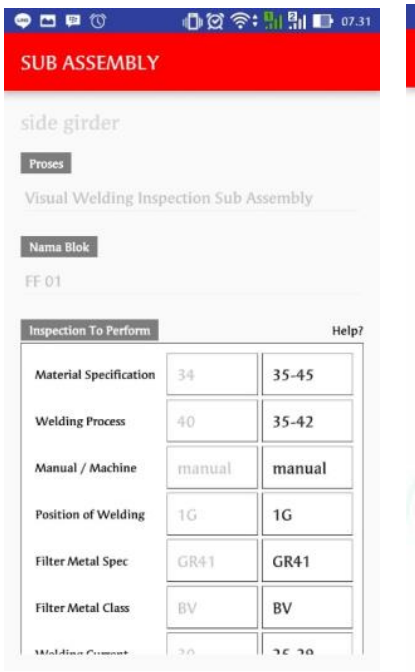

(a)

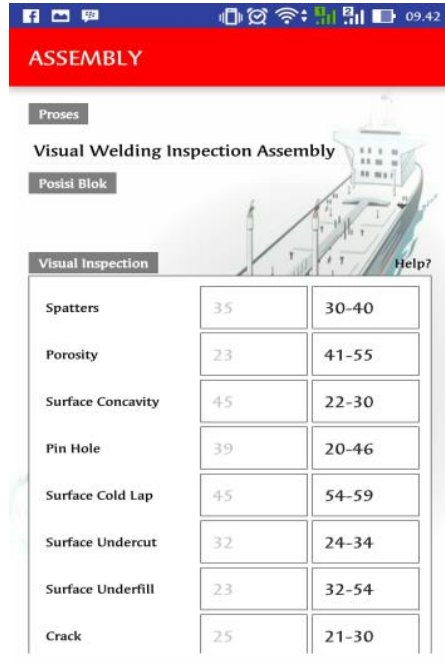

(b)
Gambar 5.(a) Form data sub assembly dan (b) Form data assembly

Gambar 5(a) merupakan form pengisian data pemeriksaan pengelasan pada tahap sub assembly kapal. Data sub assembly yang telah diisi akan tersimpan dan dapat diakses oleh User ketika melakukan pemeriksaan di lapangan. Gambar 5(b) merupakan form pengisian data pemeriksaan pengelasan pada tahap assembly kapal yang fungsinya serupa dengan sebelumnya.

- User

Welding inspector mempunyai otoritas sebagai User untuk mengisi form data yang telah tersedia. Form tersebut diisi berdasarkan pengamatan langsung dilapangan, selain itu User ini memberikan komentar terkait poin-poin yang ada didalam form. User juga dapat melakukan view report dan melakukan updating survey. Daftar otoritas Inspector;

- Mengisi form yang telah disediakan program.

- Mengubah isi di dalam form.

- Memberikan komentar terkait poin-poin didalam form.

- Mengakses survey report sebelumnya.

- Melakukan updating survey.

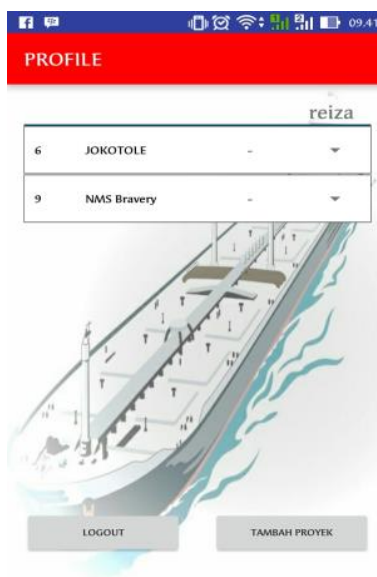

(a)

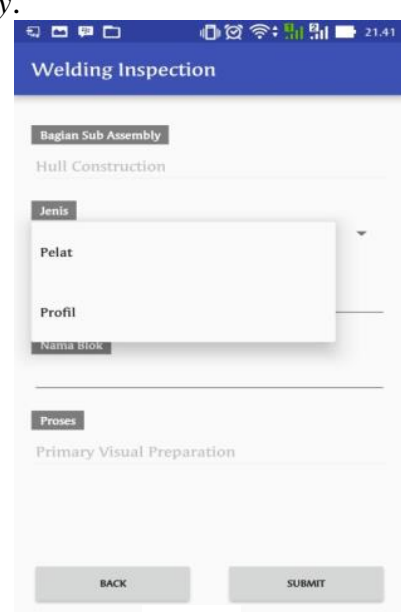

(b) 
Gambar 6(a) merupakan proses dari pemilihan kapal yang dilakukan oleh User setelah melakukan fungsi $\log \mathrm{in}$. Setelah melakukan pemilihan kapal maka dapat dilakukan pemilihan tahapan bagian kapal yang hendak di survei. Pada kondisi ini penulis akan memilih tahapan sub assembly sehingga akan ditampilkan data informasi sub assembly seperti Gambar 6(b).

\section{ANALISIS SISTEM DAN UJI COBA APLIKASI}

\section{A. Analisis Sistem}

Setelah dijelaskan pada sub bab sebelumnya, maka dapat dilihat hasil perbandingan sistem pada Tabel 2 dibawah ini.

Tabel 2.

Analisis perbandingan sistem

\begin{tabular}{|c|c|c|c|c|c|c|c|}
\hline \multirow{3}{*}{ No } & \multirow{3}{*}{ Analisa Kegiatan } & \multirow{2}{*}{\multicolumn{2}{|c|}{ Waktu }} & \multirow{2}{*}{\multicolumn{2}{|c|}{ Tempat }} & \multirow{2}{*}{\multicolumn{2}{|c|}{ Keterangan }} \\
\hline & & & & & & & \\
\hline & & Manual & Aplikasi & Manual & Aplikasi & Manual & Aplikasi \\
\hline 1 & Penyusunan Laporan Hasil Pemeriksaan & 1 hari & 30 menit & & & & \\
\hline 2 & Penyampaian Laporan Pemeriksaan & 1 hari & 1 menit & & & & \\
\hline 3 & Review Laporan Pemeriksaan & 5 menit & 10 detik & & & & \\
\hline 4 & Penyimpanan Laporan Pemeriksaan & & & Lemari & Server & & \\
\hline 5 & Pemeriksaan Pengelasan Kapal & & & & & Terencana & Terencana \& Detail \\
\hline 6 & Pengambilan keputusan & & & & & Kurang Cepat & Cepat \& Sesuai \\
\hline
\end{tabular}

Dari Tabel 2 diatas, dapat dilihat perbandingan sistem antara sistem yang digunakan sekarang dengan sistem yang menggunakan program ini. Dapat dilihat bahwa perbedaan untuk waktu dan tempat penyimpanan hasil laporan pemeriksaan pengelasan keduanya sangat signifikan. Proses yang dilakukan secara manual membutuhkan waktu yang cukup lama dalam penyusunan laporan pemeriksaan yaitu satu hari, sedangkan dengan aplikasi ini hanya membutuhkan waktu 30 menit. Hal ini dikarenakan penyusunan laporan dilakukan secara otomatis oleh sistem, bukan dilakukan secara manual dengan pengetikan menggunakan media $p c$. Media penyimpanan yang digunakan adalah server sehingga lebih praktis digunakan. User dan Administrator dapat mengirim dan mengakses data kapanpun dan dimanapun. Hal ini tentu jauh lebih efektif dibandingkan dengan penggunaan lemari berkas.

\section{B. Uji Coba Aplikasi}

Untuk menganalisis kelayakan, program diaplikasikan ke pada pihak-pihak yang memiliki pengalaman pemeriksaan pengelasan pada kapal dan pihak-pihak yang memiliki latar belakang pendidikan di bidang perkapalan. Pengujian ini dalam bentuk kuisioner untuk mengetahui respon pihakpihak yang nantinya terkait apabila program ini diaplikasikan seperti Gambar 8 dibawah.

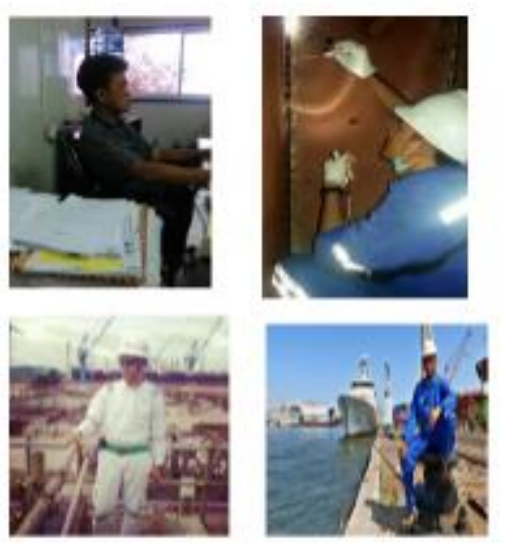

Gambar 8. Pengujian aplikasi oleh responden

\section{KESIMPULAN/RINGKASAN}

\section{A. Kesimpulan}

1. Sistem pemeriksaan pengelasan pada kapal yang ada saat ini memiliki beberapa kelemahan diantaranya memerlukan welding inspector yang memadai untuk melakukan pemeriksaan dengan benar dikarenakan kompleksnya bagian - bagian pengelasan pada kapal. Dengan menggunakan sistem survei yang lama seorang Welding Inspector membutuhkan waktu satu sampai dua hari dalam pengemasan laporan hasil pemeriksaan dan penyampaian laporan survei.

2. Dalam merancang sistem pemeriksaan pengelasan yang baru, telah dilakukan survei pemeriksaan pengelasan menggunakan prosedur pemeriksaan pengelasan yang ada dan ditentukannya parameterparameter yang akan diimplementasikan dalam bentuk aplikasi android. Terdapat dua aplikasi yang akan dirancang yaitu aplikasi untuk Administrator dan aplikasi untuk User. Aplikasi ini memiliki kelebihan yang diantaranya terdapat file panduan pemeriksaan, fitur penyampaian laporan secara terintegrasi yang dapat dimonitor, dan fitur historical data pemeriksaan sebelumnya yang dapat digunakan sebagai acuan pemeriksaan selanjutnya

3. Sistem pemeriksaan pengelasan pada bangunan kapal baru dapat diimplementasikan dalam bentuk aplikasi berbasis android. Aplikasi ini memiliki kelebihan dalam melakukan penyajian laporan secara otomatis ketika User telah melakukan pengisian form pemeriksaan ketika melakukan pemeriksaan di lapangan. Dengan sistem baru menggunakan aplikasi ini, seorang Welding Inspector dapat melakukan pengemasan laporan hasil pemeriksaan dan penyampaian hanya dalam hitungan menit. Dari hasil kuisioner dapat disimpulkan bahwa aplikasi ini sangat diperlukan dalam mendukung kegiatan pemeriksaan pengelasan pada bangunan kapal baru. 


\section{DAFTAR PUSTAKA}

[1] Wiryosumarto, Okumura. 2010. Teknologi Pengelasan Logam. Yogyakarta: Pradnya Paramitha.

[2] Widharto, Sri. 2013. Welding Inspection.Yogyakarta: Mitra Wacana Media

[3] Soeweify. 2016. Inspeksi Las. Modul Kuliah. Tidak dipublikasikan. Surabaya: Jurusan Teknik Perkapalan FTK/ITS.

[4] Manjunath. 2013. Membuat Aplikasi Android dengan Cordova. Jakarta: Gramedia.

[5] Nugroho, Bunafit. 2004. PHP dan MySQL dengan Editor Dreamweaver $M X$. Yogyakarta: Andi. 